DOI: $10.4274 /$ tftr.56.49

\title{
Respiratory Function and Respiratory Muscle Strength in Patients with Male Osteoporosis Without Kyphosis
} Kifozu Olmayan Erkek Osteoporozlu Hastalarda Solunum Fonksiyonları ve Solunum Kas Gücü

\author{
Selda BAĞIŞ, Mukadder ÇALIKOĞLU*, Melek SEZGIN**, Cengiz ÖZGE*, Özlem BÖLGEN ÇIMEN** \\ Başkent Üniversitesi Tıp Fakültesi, Adana Araştırma Hastanesi, Fiziksel Tıp ve Rehabilitasyon Anabilim Dalı, Adana, Türkiye \\ *Mersin Üniversitesi Tıp Fakültesi, Göğüs Hastalıkları Anabilim Dalı, Mersin, Türkiye \\ **Mersin Üniversitesi Tıp Fakültesi, Fiziksel Tıp ve Rehabilitasyon Anabilim Dalı, Mersin, Türkiye
}

\section{Summary}

Objective: In this study, we investigated the effect of osteoporosis on pulmonary function and respiratory muscle strength in patients with male osteoporosis with mild vertebral compression fracture, but without kyphosis or vertebral fracture.

Materials and Methods: Thirty-four men with primary osteoporosis and 17 healthy men, matched for age and weight, were evaluated. Body mass index, tobacco smoking, and degree of vertebral compression were recorded, and values for forced vital capacity (FVC), forced expiratory volume in 1 second (FEV $)$, forced expiratory flow (FEF), maximum voluntary ventilation (MVV), maximum inspiratory pressure (MIP), and maximum expiratory pressure (MEP) were determined.

Results: Although no significant differences in the results of pulmonary function tests between the patients and control groups were noted, the values for MIP $(p=0.015)$ and MEP $(p=0.008)$ were significantly lower in the osteoporotic subjects. No difference in respiratory function was noted in the subjects with compression fractures when compared to those without fractures.

Conclusion: In conclusion, we thought that osteoporosis may affect respiratory function in male patients with osteoporosis, even without kyphosis. Turk J Phys Med Rehab 2010;56:49-51.

Key Words: Osteoporosis, male, respiratory function
Özet

Amaç: Bu çalışmada hafif derecede kompresyon fraktürü olan ve fraktürü olmayan erkek osteoporozlu hastalarda, osteoporozun solunum fonksiyonları ve solunum kas gücü üzerine olan etkisini araştırdık. Gereç ve Yöntem: Otuz dört primer osteoporozlu erkek hasta ve aynı yas ve kiloda 17 sağlıklı erkek değerlendirildi. Vücut kitle indeksi, sigara içmesi, vertebral kompresyonun derecesi kaydedildi. Zorlu vital kapasite (ZVK), 1 sn'deki zorlu ekspiratuar volüm (ZEV1), zorlu ekspiratuar akım (ZEA), maksimum istemli ventilasyon (MiV), maksimum inspiratuar basınç ve maksimum ekspiratuar basınç ölçüldü.

Bulgular: Solunum fonksiyon testleri açısından hasta ve kontrol grubu arasında anlamlı farklılık saptanmazken, maksimum inspiratuar basınç ve maksimum ekspiratuar basınç değerleri osteoporotik hastalarda belirgin olarak düşüktü. Vertebral fraktürü olan ve olmayan grup arasında solunum fonksiyonları açısından fark saptanmadı.

Sonuç: Sonuç olarak osteoporozun, kifoz olmasa bile solunum fonksiyonlarını etkileyebileceği düşünüldü. Türk Fiz Tıp Rehab Derg 2010;56:49-51.

Anahtar Kelimeler: Osteoporoz, erkek, solunum fonksiyonları

\section{Introduction}

Osteoporosis is a major health problem and the main complication is a fracture. Fracture not only increases the risk of mortality, but also affect the patient's posture, functional level, and quality of life (1). Osteoporotic vertebral fractures cause paravertebral spasm, pain, and thoracic spinal deformation and may affect the respiratory system by deforming the thoracic cage and adversely affecting the function of thoracic muscles. The diaphragm, intercostal, scalene, sternocleidomastoid, pectoralis major, serratus anterior, latissimus dorsi, and abdominal muscles have a role in respiration. The effect of osteoporosis on those muscles can lead to impairment of pulmonary function (2). 
Decreased respiratory function in postmenopausal osteoporotic women with vertebral compression fractures has been demonstrated in previous studies (3-5). One of five osteoporotic patients is men, and the vertebral deformities associated with osteoporosis cause greater functional impairment in men than in women (1). Although postmenopausal osteoporotic women may exhibit impaired pulmonary function, the effects of osteoporosis in men have not been determined. The goal of this study was to investigate the effect of osteoporosis on respiratory function and muscle strength in men.

\section{Materials and Methods}

The study population consisted of 34 male patients who were diagnosed as having osteoporosis according to the World Health Organization criteria (6) and was matched in age and weight with 17 healthy men who served as controls. The results of physical examination and laboratory testing (complete blood cell count; routine biochemical evaluations; thyroid function; levels of parathormone, sex hormones, prolactin, vitamin D3, C-reactive protein, and rheumatoid factor; 24-hour urinary calcium excretion; and erythrocyte sedimentation rate) were evaluated in both groups. Men with secondary osteoporosis, primary pulmonary disease (bronchial asthma, chronic bronchitis, pulmonary fibrosis, emphysema), diabetes mellitus, cardiac disease, renal disease, a disorder of thyroid function, an inflammatory disease, or a neurologic disorder, those undergoing treatment with a medication that affects bone metabolism and with kyphosis were excluded from the study.

The height and weight of each subject were measured, and body mass index $\left(\mathrm{kg} / \mathrm{m}^{2}\right)$ was calculated. A detailed history of tobacco smoking was recorded. Subjects who had not smoked for 10 years before the study were classified as non-smoking group, and subjects who smoked at least 10 pack-years were defined as smokers.

Anteroposterior and lateral thoracic radiographs were evaluated to identify compression fractures. Vertebral deformity was scored according to the Kleerekoper's (7) method and only the patients who had grade 0 and 1 deformity were included in this study. BMD (Bone mineral density) was measured by dual energy X-ray (DXA) (Norland XR 46) at lumbar vertebrae region ( $L 2-4)$ and at femoral neck region. T-score values $<-2.5$ were accepted as indicative of osteoporosis. Pulmonary function tests were performed by a computerized spirometer (V max 22; Sensor Medics, Yorba Linda, California,
USA). Forced vital capacity (FVC), forced expiratory volume in the first second $\left(F E V_{1}\right), F E V_{1} / F V C$, maximal mid-expiratory flow rate $\left(\mathrm{FEF}_{25-75 \%)}\right.$ and maximum voluntary ventilation (MVV) were recorded. The values were expressed as a percentage of the predicted normal values, according to the European Respiratory Society (ERS) criteria (8).

Respiratory muscle strengths were assessed using a digital mouth pressure meter (MPM, Sensor Medics) and measurement of maximum inspiratory pressure (MIP) and maximum expiratory pressure (MEP) were obtained using the method of Black and Hyatt (9). Both measurements were taken three times and mean values were calculated as MIP and MEP $\left(\mathrm{cm} \mathrm{H}_{2} \mathrm{O}\right)$.

Data were analyzed using SPSS software (Statistical Package for the Social Sciences, version 9.0, SSPS Inc, Chicago, III, USA) and were expressed as mean \pm SD. Homogeneity of variance was calculated by Levene's test. The Student's t-test was used to compare the characteristics of the patients and controls. Pearson correlation analysis was used to detect the relationship between the parameters. A p value of $<0.05$ was considered statistically significant.

\section{Results}

The baseline characteristics of the patients and controls are shown in Table 1. Although there were no significant differences between patients and controls according to the results of respiratory function tests (FVC, FEV $1, F V C / F E V_{1}, F E F 25 \%-75 \%$, $M V V$ ), the MIP and MEP were significantly lower in the subjects with osteoporosis.

There was a significant correlation between the femoral neck BMD values and MIP $(p=0.007, r=0.332), \operatorname{MEP}(p=0.039$, $r=0.257)$, and MVV $(p=0.008, r=0.410)$. Fourteen $(41.17 \%)$ subjects had compression fractures. No significant differences associated with compression fractures were found in the results of respiratory function and respiratory muscle strength tests in patients when compared to controls (Table 2). Seventeen (50\%) osteoporotic subjects and $8(47 \%)$ controls were smokers, and no significant difference in respiratory function was noted between patients and controls. We also investigated the concomitant effect of smoking and vertebral compression fracture and we found the most lowest values in FVC and $\mathrm{FEV}_{1} / \mathrm{FVC}$ in this group, but in our population the number of patients with compression fractures and smoking was low $(n=8)$ and we did not compare these groups.

Table 1. Characteristics of patients and controls.

\begin{tabular}{|l|c|c|c|}
\hline & $\begin{array}{c}\text { Patients } \\
(\mathrm{n}=34)\end{array}$ & $\begin{array}{c}\text { Controls } \\
(\mathrm{n}=17)\end{array}$ & p value \\
\hline Age $(\mathrm{yr})$ & $57.3 \pm 8.48$ & $55.87 \pm 5.93$ & 0.876 \\
\hline BMl $\left(\mathrm{kg} / \mathrm{m}^{2}\right)$ & $24.79 \pm 3.36$ & $25.35 \pm 2.55$ & 0.761 \\
\hline Lumbar BMD $\left(\mathrm{g} / \mathrm{cm}^{2}\right)$ & $0.815 \pm 0.112$ & $1.120 \pm 0.119$ & $0.000^{*}$ \\
\hline Femur neck BMD $\left(\mathrm{g} / \mathrm{cm}^{2}\right)$ & $0.713 \pm 0.009$ & $0.930 \pm 0.009$ & $0.000^{*}$ \\
\hline FVC $(\%)$ & $102.76 \pm 14.41$ & $106.05 \pm 17.45$ & 0.971 \\
\hline FEV $(\%)$ & $96.85 \pm 20.93$ & $98.82 \pm 15.18$ & 0.257 \\
\hline FEV 1 FVC $(\%)$ & $72.17 \pm 10.56$ & $76.58 \pm 5.43$ & 0.732 \\
\hline FEF $25 \%-75 \%(\%)$ & $71.85 \pm 39.51$ & $77.17 \pm 25.22$ & 0.139 \\
\hline MVV $(\%)$ & $111.92 \pm 30.66$ & $126.43 \pm 20.83$ & 0.147 \\
\hline MIP $\left(\mathrm{cm} \mathrm{H} \mathrm{H}_{2}\right)$ & $71.66 \pm 19.88$ & $84.68 \pm 17.48$ & $0.015 *$ \\
\hline MEP $\left(\mathrm{cm} \mathrm{H}_{2} \mathrm{O}\right)$ & $102.21 \pm 31.04$ & $124.02 \pm 23.86$ & $0.008^{*}$ \\
\hline
\end{tabular}

BMI: body mass index, BMD: bone mineral density, FVC: forced vital capacity, FEV1: forced expiratory volume during the first second, FEF25\%-75\%: maximal mid-expiratory flow rate MVV: maximum voluntary ventilation, MIP: maximum inspiratory pressure, MEP: maximum expiratory pressure. 


\section{Discussion}

Despite conventional teaching, the evidence about osteoporotic vertebral fractures or kyphosis on pulmonary function is limited. Recently, Harrison and colleagues (10) reported a meta-analysis and showed that only 109 studies have investigated this issue since 1966 and all of them have been limited by small numbers of patients. Also, only six men have apparently ever been studied (3).

In these studies, decreased pulmonary function was found in osteoporotic women with vertebral compression fractures and kyphosis and was correlated with the severity of spinal deformation (3-5,11,12). A total of 55 women have been enrolled in the most recent study by Lombardi et al. (11) and divided into three groups: 15 with osteoporosis-related vertebral fractures, 20 with osteoporosis but without vertebral compression fractures, and 20 controls that had neither osteoporosis nor vertebral fractures. They found lower absolute values for FVC and lower $\mathrm{FEV}_{1}$ in the vertebral fractures group and they did not find any difference between the women with osteoporosis without compression fracture and control patients. Although there is no significant difference between male and female osteoporosis (13), there is no data about the effects of osteoporosis on respiratory function in men. Although only Schlaich's (3) study included men, there was no matching for age or sex, and the referral source of patients was not specified. In our study, the results of respiratory function tests were not different in subjects with osteoporosis when compared to controls. We also compared the results of the respiratory function tests of subjects with or without compression fractures and found no differences between those two groups. The results of our study may be influenced by the small number of subjects and certain characteristics of this patient population (most were young and none exhibited severe vertebral compression or thoracic deformity).

Osteoporotic compression fractures cause pain and paravertebral muscle spasm and an increase in the thoracic kyphosis angle, which therefore, may affect the inspiration and expiration. Patients did not cough effectively and the depth of inspiration was reduced. Research studies demonstrate that muscle strength, BMD and isometric muscle strength are reduced in osteoporotic patients (14), and handgrip strength and quadriceps and hamstring muscle strength are weaker in those individuals (15). Pfeifer and colleagues (16) found a positive correlation between trunk muscle strength and BMD. The respiratory muscle strength test, which determines diaphragmatic and thoracic muscle strength, is measured in MIP and MEP values. Only Leech (4) and Cimen (12) investigated the inspiratory muscle endurance in osteoporotic patients and reported that MIP and MEP values were lower in osteoporotic

Table 2. Results of respiratory function tests and respiratory muscle strength of male osteoporotic subjects with or without compression fractures.

\begin{tabular}{|l|c|c|c|}
\hline & $\begin{array}{c}\text { Compression } \\
\text { fractures }(n=14)\end{array}$ & $\begin{array}{c}\text { No compression } \\
\text { fractures }(n=20)\end{array}$ & $p$ value \\
\hline $\mathrm{FVC} \mathrm{( \% )}$ & $103.83 \pm 16.04$ & $111.40 \pm 20.36$ & 0.256 \\
\hline $\mathrm{FEV}(\%)$ & $93.90 \pm 20.61$ & $98.08 \pm 21.38$ & 0.603 \\
\hline $\mathrm{FEV} 1 / \mathrm{FVC}(\%)$ & $67.80 \pm 12.89$ & $74.0 \pm 9.12$ & 0.120 \\
\hline $\mathrm{FEF} 25 \%-75 \%(\%)$ & $58.20 \pm 33.15$ & $77.54 \pm 41.17$ & 0.198 \\
\hline $\mathrm{MVV}(\%)$ & $110.47 \pm 31.01$ & $118.00 \pm 31.80$ & 0.632 \\
\hline $\mathrm{MIP}\left(\mathrm{cm} \mathrm{H} \mathrm{H}_{2} \mathrm{O}\right)$ & $71.97 \pm 14.45$ & $71.99 \pm 20.88$ & 0.998 \\
\hline $\mathrm{MEP}\left(\mathrm{cm} \mathrm{H} \mathrm{H}_{2} \mathrm{O}\right)$ & $97.99 \pm 30.80$ & $111.55 \pm 34.73$ & 0.234 \\
\hline
\end{tabular}

FVC: forced vital capacity, FEV1: forced expiratory volume during the first second, FEF 25\%-75\%: maximal mid-expiratory flow rate, MVV: maximum voluntary ventilation, MIP: maximum inspiratory pressure, MEP: maximum expiratory pressure. patients with compression fractures. These findings are consistent with the results of our study.

Smoking has a negative effect on bone metabolism and is a major cause of respiratory disorders resulting in impaired $\mathrm{FEV}_{1}(17)$. According to Harrison's (10) meta-analysis, only Lombardi et al. (11) excluded the smokers in their study and the other studies did not investigate the effects of smoking. In our study, we investigated the effects of smoking on the respiratory system and found no difference between subjects and controls with regard to smoking status or respiratory system function.

This study showed that in osteoporotic patients, the results of respiratory function tests did not change, while respiratory muscle strength was significantly reduced when comparing them with controls. We concluded that osteoporosis can affect respiratory muscle strength in men, regardless of the presence of vertebral deformity. Additional studies on large numbers of patients with severe compression fractures are needed to clarify this issue.

\section{References}

1. Burger $H$, Van Daele $P L$, Grashuis $K$, Hofman A, Grobbee DE, Schutte $\mathrm{HE}$, et al. Vertebral deformities and functional impairment in men and women. J Bone Miner Res 1997;12:152-7. [Abstract] / [Full Text] / [PDF]

2. Celli BR. Clinical and physiologic evaluation of respiratory muscle function. Clin Chest Med 1989;10:199-214. [Abstract]

3. Schlaich C, Minne HW, Bruckner T, Wagner G, Gebest HJ, Grunze M, et al. Reduced pulmonary function in patients with spinal osteoporotic fractures. Osteoporos Int 1998;8:261-7. [Abstract] / [PDF]

4. Leech JA, Dulberg C, Kellie S, Pattee L, Gay J. Relationship of lung function to severitv of osteoporosis in women. Am Rev Respir Dis 1990:141:68-71. [Abstract]

5. Culham EG, Jimenez HA, King CE. Thoracic kyphosis, rib mobility, and lung volumes in normal women and women with osteoporosis. Spine 1994;19:1250-5. [Abstract]

6. Assessment of fracture risk and its application to screening for postmenopausal osteoporosis. Report of a WHO Studv Group. World Health Organ Tech Rep Ser 1994;843:1-129. [Abstract]

7. Lems WF, Jehangier ZN, Raymakers A, Jacobs JW, Bijlsma JW. Method to score vertebral deformities in patients with rheumatoid arthritis. Br J Rheum 1997;36:220-4. [Abstract] /[PDF]

8. Quanjer $\mathrm{PH}$, Tammeling GJ, Cotes JE, Pedersen OF, Peslin $\mathrm{R}$ Yernault JC. Lung volumes and forced ventilatory flows. Report Working Party Standardization of Lung Function Tests, European Community for Steel and Coal. Official Statement of the European Respiratory Society. Eur Respir J Suppl 1993;16:5-40. [Abstract]

9. Black LF, Hyatt RE. Maximal respiratory pressures: normal values and relationship to age and sex. Am Rev Respir Dis 1969;99:696-702. [Abstract]

10. Harrison RA, Siminoski K, Venthanayagam D, Majumdar SR. Osteoporosis-related kyphosis and impairments in pulmonary function: A systematic review. J Bone and Min Res 2007:27:447-57.

11. Lombardi I, Oliveria LM, Mayer AF, Jardim JR, Natour J. Evaluation of pulmonary function and quality of life in women with osteoporosis. Osteoporos Int 2005;16:1247-53. [Abstract] / [Full Text] / [PDF]

12. Cimen OB, Ulubas B, Sahin G, Calikoglu M, Bagis S, Erdogan C. Pulmonary function tests, respiratory muscle strength, and endurance of patients with osteoporosis. South Med J 2003;96:423-6. [Abstract] / [Full Text] / [PDF]

13. Orwoll ES, Bliziotes M. Heterogeneity in osteoporosis. Men versus women. Rheum Dis Clin North Am 1994;20:671-89. [Abstract]

14. Humphries B, Triplett-McBride $T$, Newton RU, Marshall S, Bronks R, McBride J, et al. The relationship between dynamic, isokinetic and isometric strength and bone mineral density in a population of 45 to 65 year old women. J Sci Med Sport 1999;2:364-74. [Abstract]

15. Kerschan K, Alacamlioglu Y, Kollmitzer J, Wober C, Kaider A, Hartard M, et al. Functional impact of unvarying exercise program in women after menopause. Am J Phys Med Rehabil 1998;77:326-32. [Abstract]

16. Pfeifer $M$, Begerow B, Minne HW, Schlotthauer T, Pospeschill M, Scholz M, et al. Vitamin D status, trunk muscle strength, body sway, falls, and fractures among 237 postmenopausal women with osteoporosis. Exp Clin Endocrinol Diabetes 2001;109:87-92. [Abstract] / [Full Text] / [PDF]

17. Barnes PJ. Chronic obstructive pulmonary disease. N Engl J Med 2000;343:269-80. [Abstract] / [Full Text] / [PDF] 